УДК [343.2:343.3/.7] (477)

DOI https://doi.org/10.32849/2663-5313/2020.7.49

\title{
Тетяна Михайліченко,
}

канд. юрид. наук,

доцент кафедри кримінального права та кримінально-правових дисциплін

Полтавського юридичного інституту

Начіонального юридичного університету імені Ярослава Мудрого

\section{КРИМІНАЛЬНІ ПРОСТУПКИ: ОСОБЛИВОСТІ ПРАВОВОГО РЕГУЛЮВАННЯ}

У роботі здійснено критичний аналіз концептуальних положень Закону Украйни «Про внесення змін до деяких законодавчих актів України щодо спрощення досудового розслідування окремих категорій кримінальних правопорушень» № 2617-VIII від 22.11.2018 р., який вніс зміни до Кримінально$2 о$ кодексу України, встановивши кримінальну відповідальність за вчинення особою кримінального проступку, в розрізі виявлення прогалин та колізій. У зв'язку із появою кримінального проступку в начіональному кримінальному законодавстві останнє зазнало значних змін та доповнень, які переформатували окремі традииійні підходи в кримінальному праві Украйни. Насамперед було виконано перерозподіл всіх правопорущень, які передбачені КК України, на кримінальні проступки, нетяжкі, тяжкі та особливо тяжкі злочини. Також у більшості випадків відбулося посилення кримінальної відповідальності передусім шляхом збільшення розміру такого покарання як штраф. Окрім иього, була встановлена непропориійність при змінах ставок штрафу.

3'ясовано співвідношення між «кримінальним правопорушенням», «злочином» $i$ «кримінальним проступком», здійснено аналіз положень ст. 12 КК та й вплив на інші положення КК України. В низиі випадків виявлені неточності чи прогалини, а саме при регламентаиї̈ звільнення від кримінальної відповідальності, звільнення від відбування покарання у зв'язку із закінченням строків давності виконання обвинувального вироку та заходів кримінально-правового характеру, що застосовуються до юридичних осіб (статті 45, 46, 80, 97, ч. 2 cm. 96-7 та ч. 2 cm. 106 КК України).

Досліджено повторність як ознаку, яка характеризує кваліфіковані (особливо кваліфіковані) склади кримінальних правопорушень, та як обставину, яка обтяжує покарання. Виявлено прогалини при конструюванні ст. 32 КК України. Також піддаються критииі упущення в заміні терміну «злочин» на «кримінальне правопорушення» у ст. 10 та пунктах 1, 5, 10, 11 та 12 ч. $2 \mathrm{~cm} .67$ КК України.

Пропонується якнайшвидше скоригувати положення ст. $10 \mathrm{ma} \mathrm{cm.} 67$ КК Украйни, замінивши злочин на кримінальне правопорушення, привести положення Закону України «Про застосування амністї̈ в Украӥні» у відповідність з чинним КК України, а також усунути виявлені дискриміначійні положення у ст. 32 та 89 КК України.

Ключові слова: кримінальне правопорушення, злочин, кримінальний проступок, кримінальна відповідальність, повторність кримінальних правопорушень, обставини, які обтяжують покарання, санкція, судимість.

Постановка проблеми. 1 липня 2020 р. набрав чинності Закон України «Про внесення змін до деяких законодавчих актів України щодо спрощення досудового розслідування окремих категорій кримінальних правопорушень» № 2617-VIII від 22 листопада 2018 р. (далі - Закон № 2617VIII), який ввів до Кримінального кодексу (далі - КК) України кримінальний проступок, що було однією із найобговорюваніших у науково-практичних колах тем останнього десятиліття. При цьому науковопрактична спільнота, особливо спеціалісти 3 кримінально-процесуального права, загалом схвально, хоча і з певними застереженнями, сприйняла новели, аргументуючи їх необхідність насамперед потребою набли-

зити наше законодавство до європейського, уникнути ймовірності незабезпечення права на захист, економією кримінальних репресій, зменшенням навантаження на слідчі органи досудового розслідування та ін.

Водночас 17 червня 2020 р. було прийнято Закон «Про внесення змін до деяких законодавчих актів України у зв'язку з прийняттям Закону України «Про внесення змін до деяких законодавчих актів України щодо спрощення досудового розслідування окремих категорій кримінальних правопорушень» № 720-IX, яким законодавець намагався скорегувати окремі недоліки базового Закону (але загалом ці корективи стосувалися положень Особливої частини КК а не тих недоліків, які нами виявлені). Окрім 
цього, він мав набрати чинності одночасно із Законом № 2617-VIII, але de-facto набрав чинності лише 03.07.2020р., що утворило чергові труднощі у правозастосуванні.

У той же час дослідження останніх публікацій з цієї теми, зокрема, таких учених, як: А.А. Васильєв, О.П. Горпинюк, І.О. Зінченко, I.В. Красницький, О.С. Пироженко, свідчить про те, що аналіз змін і доповнень до КК України, внесені Законом № 2617-VIII, мають фрагментарний характер, а основна дискусія серед науковців протягом багатьох років розгорталася стосовно таких питань, як: природа кримінального проступку та кримінального правопорушення, співвідношення злочину та кримінального проступку, а також доцільність введення останнього до кримінального законодавства України (Д.С. Азаров, В.К. Грищук, Н.О. Гуторова, О.О. Дудоров, К.П. Задоя, В.О. Навроцький, В.Я. Тацій, B.I. Тютюгін, Є.Л. Стрельцов, В.О. Туляков, П.Л. Фріс, М.І. Хавронюк та багато інших вчених).

Метою статті $є$ комплексне дослідження концептуальних положень та, які набрали чинності 1 липня 2020 р. та суттєво змінили КК України, задля сприяння роботі практичних працівників з новими положеннями кримінального законодавства, виявлення колізій та прогалин і формулювання пропозицій щодо усунення недолік ків, які містить Закон № 2617-VIII.

Виклад основного матеріалу. Виходячи із поставленої мети, буде розглянуто норми Закону № 2617-VIII, який виділив у КК України понад 80 складів кримінальних проступків, легалізуючи це поняття в українському кримінальному законодавстві, при цьому буде зосереджена увага на положеннях Загальної частини, бо перетрубації в них дуже змінили добре всім відомий кримінальний закон.

1. Нині в КК України маємо такі поняття, як: 1) «кримінальне правопорушення», визначення якого законодавець наводить у ч. 1 ст. $11 \mathrm{KK}^{1}, 2$ ) «злочин» та 3 ) «кримінальний проступок».

Яке це має значення? «Кримінальне правопорушення» нині виступає родовим поняттям щодо «злочину» та «кримінального проступку», а отже, при кваліфікації діяння за КК України у редакції від 01.07.2020р. правозастосувач має остаточно вирішити, що вчинила винна особа: кримінальний просту-

1 Це передбачене цим Кодексом суспільно небезпечне винне діяння (дія або бездіяльність), вчинене суб'єктом кримінального правопорушення. пок, передбачений ч. 1 ст. 185 КК України, чи злочин (частини 2-5 ст. 185 КК відповідно), оскільки в подальшому це матиме значення для кримінально-правових наслідків вчинення кримінального правопорушення.

При цьому розрізняти кримінальний проступок та злочин законодавець пропонує фактично за допомогою виду та міри покарання, що видається, на нашу думку, не найкращим варіантом для такого розмежування. Хоча первинно кримінальні проступки мали б бути насамперед «створені» за рахунок багатьох адміністративних правопорушень (які «ховаються» у Кодексі про адміністративні правопорушення) і деяких злочинів невеликої тяжкості. Однак ця мета так і не була досягнута.

Додатково слід відмітити справедливість зауваження I.В. Красницького та О.П. Горпинюк, що формальне перейменування злочину на кримінальне правопорушення у низці випадків видається невиправданим (зокрема, у ст. 107 КК України, адже умовно-дострокове звільнення може застосовуватися лише до неповнолітніх осіб, які відбули певну частку від призначеного строку покарання у виді позбавлення волі за нетяжкий, тяжкий чи особливо тяжкий злочин; можливість умовно-дострокового звільнення за вчинення кримінального проступку не передбачена) [1, с. 18].

2. Суттєвих змін зазнала і ст. 12 КК України.

Так, у ч. 2 цієї статті нині надається легальне визначення кримінального проступку і вказано, що ним є передбачене цим Кодексом діяння (дія чи бездіяльність), за вчинення якого передбачене основне покарання у виді штрафу в розмірі не більше 3000 неоподатковуваних мінімумів доходів громадян (далі - н.м.д.г.) або інше покарання, не пов'язане з позбавленням волі.

Крім цього, законодавець відмовився від звичного нам поділу злочинів за тяжкістю і тепер ми маємо нетяжкі, тяжкі та особливо тяжкі злочини (ч. 3 ст. 12 КК України). При цьому фактично законодавець механічно поділив злочини невеликої тяжкості на дві підгрупи: 1) які мають штраф до 3000 н.м.д.г. та не передбачають позбавлення волі та 2) які передбачають в санкції частини статті штраф понад 3000 н.м.д.г. та/або позбавлення волі. I об'єднав другу підгрупу із «старими» 3лочинами середньої тяжкості, перейменувавши ïx на «нетяжкі злочини». До того ж, мають місце випадки, коли в окремих «старих» злочинах середньої тяжкості було замінене позбавлення волі на обмеження волі, таким чином переводячи цей злочин до категоpiї кримінальних проступків (приміром, ч. 1 ст. 185 КК України). 
Постає питання: чи є це виправданим та чи підпадає такій підхід під гуманістичні тенденції? На нашу думку, навряд чи. Адже, щоб перевірити справедливість нашої позиції, можна, приміром, порівняти попередню та чинну редакції ст. 45 КК України «Звільнення від кримінальної відповідальності у зв'язку з дійовим каяттям» (табл. 1).

Ця порівняльна таблиця яскраво свідчить, що якщо раніше особа могла бути звільнена від кримінальної відповідальності у зв'язку із дійовим каяттям за: 1) умисний чи необережний злочин невеликої тяжкості або 2) необережний злочин середньої тяжкості. Натомість нині у зв'язку із перерозподілом категорій злочинів, особи, які вчинили всі умисні правопорушення, санкції статей яких передбачають штраф понад 3000 н.м.д.г. та/або позбавлення волі, не можуть бути звільнені від кримінальної відповідальності на підставі ст. 45 КК України.

Аналогічна ситуація склалася й при звільненні від кримінальної відповідальності на підставі статей 46 та 97 КК України.

Посилення кримінальної відповідальності у зв’язку зі зміною поділу кримінальних правопорушень (в тому числі й злочинів) на види призвели і не до суттєвих, здавалося б, змін у ст. 80 КК України (табл. 2).
Але як видно із порівняльної таблиці, знову ж таки для осіб, які були засуджені в період дії редакції КК України, яка втратила зараз чинність (до 01.07.2020р.), до позбавлення волі за злочин невеликої тяжкості, строк давності є коротшим, ніж для тих, що вчинили злочин, які перетворилися на нетяжкі за чинною редакцією кримінального закону.

До речі, аналогічний недолік міститься і в ч. 2 ст. 106 КК України.

Також вбачається, що для окремих громадян, враховуючи і положення ч. 4 ст. 84 КК України $^{2}$, це матиме додатковий негативний наслідок.

Окрім того, у цій же статті наявний такий нюанс: згідно із ч. 4 ст. 80 КК України строки давності перериваються виключно, якщо засуджений вчинить новий злочин. Не кримінальне правопорушення, а саме злочин. А це означає, що вчинення засудженим кримінального проступку (одного чи, навіть, кількох) не матиме жодних правових наслідків для перебігу строків давності. І можливо це і має сенс, але що робити якщо особа веде явно «злочинний» спосіб життя? I чому тоді для переривання строків давності вчинення особою кримінального проступку значення немає, а для правових наслідків звільнення від відбування покарання 3 випробуванням

Таблиця 1

\begin{tabular}{|l|}
\hline \multicolumn{1}{|c|}{ Попередня редакція ст. 45 Кк } \\
\hline Особа, яка вперше вчинила злочин невеликої тяж- \\
кості або необережнии злочин середнъої тяжкості \\
(тут і далі курсив наш - Т.М.), крім корупційних \\
злочинів, звільняється від кримінальної відпові- \\
дальності, якщо вона після вчинення злочину щиро \\
покаялася, активно сприяла розкриттю злочину \\
і повністю відшкодувала завдані нею збитки або \\
усунула заподіяну шкоду
\end{tabular}

Чинна редакція ст. 45 КК

Особа, яка вперше вчинила кримінальний проступок або необережний нетяжкий злочин, крім корупційних кримінальних правопорушень, звільняється від кримінальної відповідальності, якщо вона після вчинення кримінального правопорушення щиро покаялася, активно сприяла розкриттю кримінального правопорушення i повністю відшкодувала завдані нею збитки або усунула заподіяну шкоду.

Таблиця 2

\begin{tabular}{|c|c|}
\hline Попередня редакція ст. 80 КК & Чинна редакція ст. 80 КК \\
\hline $\begin{array}{l}\text { Особа звільняється від відбування покарання, } \\
\text { якщо } 3 \text { дня набрання чинності обвинувальним } \\
\text { вироком його не було виконано в такі строки: } \\
\text {.. } \\
\text { 2) } 3 \text { роки - у разі засудження до покарання у виді } \\
\text { обмеження волі або позбавлення волі за злочин неве- } \\
\text { ликої тяжкості; } \\
\text { 3) } 5 \text { років - у разі засудження до покарання у виді } \\
\text { позбавлення волі за злочин середньої тяжкості, } \\
\text { а також при засудженні до позбавлення волі на } \\
\text { строк не більше п'яти років за тяжкий злочин; } \\
\text {... }\end{array}$ & $\begin{array}{l}\text { 1. Особа звільняється від відбування покарання, } \\
\text { якщо } 3 \text { дня набрання чинності обвинувальним } \\
\text { вироком його не було виконано в такі строки: } \\
\ldots \\
\text { 2) } 3 \text { роки - у разі засудження до покарання у виді } \\
\text { обмеження волі; } \\
\text { 3) } 5 \text { років - у разі засудження до покарання у виді } \\
\text { позбавлення волі за нетяжкий злочин, а також при } \\
\text { засудженні до позбавлення волі на строк не більше } \\
\text { п'яти років за тяжкий злочин; } \\
\text {... }\end{array}$ \\
\hline
\end{tabular}

2 У разі одужання осіб, зазначених у частинах першій та другій цієї статті, вони повинні бути направлені для відбування покарання, якщо не закінчилися строки давності, передбачені статтями 49 або 80 цього Кодексу, або відсутні інші підстави для звільнення від покарання. 
(див. частини 1 та 2 ст. 78 КК України) має? Правильної відповіді на це питання поки немає. Та на нашу думку, це недолік вказаного положення, який має дискримінаційний характер.

Не менш помітною прогалиною видається й упущення стосовно внесення відповідних змін до Закону України «Про застосування амністії в Україні» (1996), який діє в редакції від 14.05.2014 р., оскільки цей нормативно-правовий акт досі оперує лише поняттям «злочин» і не знає ні «кримінального правопорушення», ні «кримінального проступку». Хоча у ст. 86 КК України відповідні зміни були внесені. Тобто можна припустити, що у випадку вчинення кримінального проступку особа не буде підлягати звільненню за амністією. I якщо особі призначили штраф, то можливо амністія i не потрібна (хоча чому для осіб, які вчиняють більш суспільно небезпечні посягання (злочини) вона передбачена, а для тих, хто вчинив проступок - ні?). Але що робити, якщо особі призначений арешт чи обмеження волі? Чи не $є$ і тут ознаки дискримінації?

3. Доцільним також $€$ зупинитися на дослідженні положень ст. 32 КК України. На нашу думку, положення про повторність кримінальних правопорушень стануть однією із найскладніших та дискусійних проблем для правозастосувачів. Так, з одного боку, ст. 32 КК України зазнала механічного заміщення поняття злочину на поняття кримінальний проступок. Однак, якщо за загальним правилом для наявності повторності, як і раніше, не мають значення стадії кримінальних правопорушень, які входять до повторності. То зараз повторність відсутня якщо в неї входить готування до кримінального проступку чи злочину, за який статтею Особливої частини КК передбачене покарання у виді позбавлення волі на строк до двох років або інше більш м'яке покарання. В таких випадках відповідно до ч. 1 ст. 14 КК особа не притягається до кримінальної відповідальності, а отже, це не враховуються і при визначенні повторності кримінальних правопорушень. I, як слушно наголошуе I.O. Зінченко, «при повторності мають зберігати своє кримінально-правове значення хоча б два кримінальних правопорушення, що її утворюють» [2, с. 193]. Але, з іншого боку, треба враховувати, що деякі злочини навіть середньої тяжкості тепер є кримінальними проступками. Тобто в ситуації виявлення, приміром, готування до вчинення крадіжки та замаху на шахрайство повторність нині відсутня. Наскільки це правильно, покаже час.
Також варто враховувати, що повторність на практиці є дуже поширеною і може враховуватися або як кваліфікуюча (особливо кваліфікуюча) ознака складу кримінального правопорушення, або як обставина, яка обтяжує покарання.

I тут варто відмітити про ще один недолік: у п. 1 ч. 1 ст. 67 КК України зміни не були внесені, тому там фігурує лише повторність та рецидив злочинів. Тобто вчинення кримінального проступку в період, коли особа, приміром, ще не відбула попереднє покарання за злочин чи інший проступок не обтяжуватиме покарання.

Також тепер крадіжка та шахрайство - це кримінальні правопорушення, які в одній нормі (ст. 185 та ст. 190 КК України відповідно), але у різних частинах статей, передбачають у діях особи вчинення кримінального проступку (ч. 1) та злочину (частина 2 та наступні). Однак в обох цих статтях частина 2 передбачає повторність як кваліфікуючу ознаку складу кримінального правопорушення. I вже зараз можна змоделювати дві ситуації:

(1) особа вчиняє крадіжку, іiї засуджують за ч. 1 ст. 185 КК України і присуджують виплату штрафу (щодо розміру штрафу i його гуманності йтиметься далі), який вона одномоментно виплачує і відповідно до п. 2-1 ч. 1 ст. 89 КК України відразу після цього вважається такою, яка немає судимості. Вже через 3 місяці ця ж особа вчиняє нове кримінальне правопорушення, приміром, шахрайство. Але, враховуючи положення ч. 4 ст. 32 КК, її дії будуть кваліфіковані лише за ч. 1 ст. 190 КК;

або

(2) особа вчиняє крадіжку, їі засуджують за ч. 1 ст. 185 КК України і присуджують штраф, який призначають, враховуючи iï майновий стан, виплачувати із розстрочкою протягом 9 місяців. За таких умов до моменту сплати повної суми штрафу відповідно до п. 2-1 ч. 1 ст. 89 КК України особа вважається такою, що має судимість. I якщо через 3 місяці ця ж особа вчиняє нове кримінальне правопорушення, те ж саме, шахрайство, то враховуючи положення ч. 4 ст. 32 КК України, її дії будуть кваліфіковані вже за ч. 2 ст. 190 КК України.

Постають питання: чи забезпечена в такій ситуація рівноправність громадян? Чи не вбачаються тут ознаки дискримінації за майновим станом особи, яка вчинила злочин і яка може або, навпаки, не може сплатити штраф одномоментно?

Окрім того, правильно пише I.O. Зінченко: «повторність злочинів має місце як y тих випадках, коли за перший із вчинених 
злочинів особу ще не було засуджено, так і у випадках, коли після засудження, але до погашення чи зняття судимості, особою було скоєно новий злочин» [2, с. 194].

4. Також окремо слід відмітити, що науковцями висловлені й інші зауваження стосовно положень про судимість. Зокрема, на думку А.А. Васильєва та О.С. Пироженко, на практиці можуть виникнути труднощі під час застосування п. 4 ч. 1 ст. 89 КК України до «особи, засудженої до покарання у виді службових обмежень для військовослужбовців або тримання в дисциплінарному батальйоні військовослужбовців за вчинення кримінального проступку (наприклад, ч. 1 ст. 412 КК України)» [3, с. 79]. I хоча ці види покарань достатньо рідко призначаються судом, але ситуація є цілком ймовірною, а тому варто погодитися 3 дослідниками, що ця проблема мала б бути заздалегідь вирішена.

Безсумнівно правильними, на нашу думку, є й застереження з приводу несправедливості у випадках, коли штраф буде призначеним за вчинення кримінального правопорушення у розмірі до 3000 н.м.д.г. Оскільки, якщо засуджений вчинив злочин, то він перебуватиме у стані судимості протягом року після сплати штрафу. А якщо кримінальний проступок, то судимість буде автоматично погашено відразу ж після відбуття даного покарання, тобто після виплати штрафу [1, с. $18-19 ; 3$, с. 80].

5. Помітним та зовсім позбавленим проявів гуманізму, на нашу думку, є й зміни до окремих санкцій статей Особливої частини, на що звертав увагу В. В. Шаблистий [4]. Дійсно, вводячи до КК України кримінальні проступки, законодавець у 129 складах правопорушень посилив кримінальну відповідальність. Серед найбільш поширених кримінальних правопорушень, санкція яких стала більш суворою можна вказати такі, як: крадіжка, грабіж, шахрайство, привласнення або розтрата чужого майна, а також окремих т.зв. наркозлочинів (нині більш точно, мабуть, наркоправопорушень).

Натомість аналіз положень Закону № 2617-VIII свідчить, що лише у статтях 175, ч. 2 ст. 309 , ст. 350 КК України санкція стала більш м'якою, а в ч. 1 ст. 185 , ч. 1 ст. 190 , ст. 253 , ч. 1 ст. 298 , ч. 1 ст. 299 , ч. 1 ст. 309 , ч. 1 ст. 365-2 КК України вона стала лише частково м'якшою. При цьому, окремі невідповідності положень Загальної частини КК

3 Не менш яскравою ілюстрацією непропорційності є зміни розмірів штрафів у статтях 286 , 287 та 291 КК України та ін.
України та санкції статті у розмірах такого покарання як позбавлення права обіймати певні посади чи займатися певною діяльністю були перенесені в чинну редакцію (приміром, ч. 1 ст. 365-2 КК України).

Первинно мало місце і доповнення КК України новим злочином - керування транспортними засобами в стані алкогольного, наркотичного чи іншого сп'яніння або під впливом лікарських препаратів, що знижують увагу та швидкість реакції (ст. 286-1 КК України). Та він був чинним лише кілька днів і нині скасований Законом «Про внесення змін до деяких законодавчих актів України у зв'язку з прийняттям Закону України «Про внесення змін до деяких законодавчих актів України щодо спрощення досудового розслідування окремих категорій кримінальних правопорушень»» № 720-IX. Однак питання наслідків такого законотворення, на нашу думку, потребує самостійного грунтовного дослідження.

Також не вдаючись до аналізу заміни самих розмірів покарань, хоча вони часто надто очевидно непропорційні (наприклад, якщо за ч. 1 ст. 185 КК України штраф тепер може призначатися у розмірі від 1000 н.м.д.г. до 3000 н.м.д.г. (раніше від 50 до 100 н.м.д.г.), то за ч. 1 ст. 190 КК України - від 2000 н.м.д.г. до 3000 н.м.д.г. (раніше до 50 н.м.д.г.), хоча ці злочини є дуже близькими за рівнем суспільної небезпеки $)^{3}$, хотілося б підняти проблему виконання таких покарань. У ситуації, коли особа шляхом обману заволодіє чужим майном на суму від 0,2 до 100 н.м.д.г. (у 2020 р. це від 210,2 до 105100 грн.), то ії дії підпадатимуть під ч. 1 ст. 190 КК України. Отже, із високою вірогідністю суд призначить за заволодіння 500 грн. шахраєві саме штраф, тобто щонайменше 34000 грн., які не кожна особа може сплатити. А тому постає питання: якщо суд не бачитиме причин звільнити від кримінальної відповідальності чи покарання або призначати більш суворі види покарань шахраєві, то останній має сплачувати штраф, який не гарантовано, що виплатить. За таких умов особа має шанси отримати вже новий вирок за ст. 389 КК України «Ухилення від покарання, не пов'язаного з позбавленням волі». Наскільки це є виправдано? I чи не призведе це до такої ж ситуації, яка є з господарськими кримінальними правопорушеннями, коли суд уточнює до винесення вироку чи зможе обвинувачений його сплатити?

Окрім непропорційності збільшення покарань маємо ще й відсутність при цьому уніфікованого підходу. Наприклад, в одному випадку штраф у розмірі від 100 до 200 н.м.д.Г. замінено на штраф від 1000 до 4000 н.м.д.г. (ст 267 КК України), а в іншому - лише до 3000 н.м.д.г. (ст. 271 КК України). 
6. Також не менш хвилюючим є й те, що зараз за буквального тлумачення положень ст. 10 КК України наша держава може видавати своїх громадян іноземній державі для притягнення до кримінальної відповідальності та віддання до суду якщо вони вчинили кримінальний проступок, а не злочин поза межами України! Така ж ситуація і з іноземцями та особами без громадянства. Окрім цього Україна може перейняти кримінальне провадження, в якому судовими органами іноземної держави не ухвалено вирок, щодо громадян України та іноземців, які вчинили лише злочини за межами України і перебувають на території України, але які не можуть бути видані іноземній державі або у видачі яких відмовлено, якщо діяння, у зв'язку з яким запитується передача кримінального провадження, згідно з цим Кодексом визнається злочи ном. Тобто тепер маємо ситуацію, що якщо громадянин України вчинить кримінальний проступок, то перейняти кримінальне провадження щодо нього ми не можемо, а видати - можемо.

7. Доцільно відмітити й застереження щодо обставин, які обтяжують покарання, то не лише у ситуації з повторністю наявне упущення. Оскільки у п. 5 ч. 1 ст. 67 КК України обставиною, яка обтяжує покарання, залишилися тяжкі наслідки, завдані злочином; у п. 10 - вчинення злочину з особливою жорстокістю; у п. 11 - вчинення злочину з використанням умов воєнного або надзвичайного стану, інших надзвичайних подій; а також у п. 12 - вчинення злочину загальнонебезпечним способом. Постає питання: а чи не може в перспективі виникнути ситуація, коли тяжкі наслідки будуть спричинені саме кримінальним проступком, a не злочином? Приміром, при невиплат заробітної плати (ст. 175 КК України), розголошенні комерційної або банківської таємниці (ст. 232 КК України) тощо. Або будуть використані умови воєнного стану, особливо з урахуванням фактично безперервних воєнних дій на Донбасі (наприклад, блокування транспортних комунікацій (ч. 1 ст. 279 КК України)? Або з використанням загальнонебезпечного способу?

8. Можна також відмітити, що зміни у ст. 12 КК України мають наслідки і для юридичних осіб, якщо до них будуть застосовані заходи кримінально-правового характеру. Зокрема, це змінило межі штрафу, який буде призначений юридичній особі (ч. 2 ст. 96-7 КК України), у разі, коли неправомірну вигоду не було одержано, або iii розмір неможливо обчислити, оскільки прив'язка меж відбувається до тяжкості кримінального правопорушення.

\section{Висновки}

Проведений аналіз новел до КК України дозволяє констатувати їх несистемний характер, наявність окремих необгрунтованих положень, які потрібно якомога швидше виправляти, а також порушень основоположних правових принципів. 3 урахуванням того, що з моменту прийняття Закону № 2617-VIII і до набрання ним чинності пройшло понад півтора року, видається не зрозумілим підхід законодавця до внесення змін.

За таких умов для нормальної роботи практичним працівникам щонайменше видається доцільним: 1) скоригувати положення ст. 10 та ст. 67 КК України, замінивши злочин на кримінальне правопорушення; 2) такі ж зміни внести до Закону України «Про застосування амністії в Україні» (1996); 3) усунути виявлені дискримінаційні положення у ст. 32 та 89 КК України.

\section{Список використаних джерел:}

1. Красницький I.В., Горпинюк О.П. Запровадження кримінальних проступків: аналіз змін до законодавства. Кримінальне та кримінальне прочесуальне законодавство у контексті реформи кримінальної юстииії : матеріали наук.-практ. семінару (31.05.2019 р., м. Львів). Львів: Львів. держ. ун-т внутр. справ. 2019. С. $17-21$.

2. Зінченко І.О. До питання щодо удосконалення поняття повторності кримінальних правопорушень у чинному Кримінальному кодексі України. Концептуальні засади нової редакції Кримінального кодексу України : матеріали міжнар. наук. конф. (17-19.10.2019 р., м. Харків) / редкол.: В.Я. Тацій, А.П. Гетьман, Ю.В. Баулін та ін. Харків : Право, 2019. С. 192-197.

3. Васильєв А.А., Пироженко О.С. До питання про судимість як наслідок засудження за вчинення кримінального проступку. Кримінальне право в умовах глобалізачії суспільних процесів: традищіі та новації : матеріали міжнар. наук.практ. круглого столу (15.05.2020 р., м. Харків) / редкол.: В. Я. Тацій, Л. М. Демидова, А. П. Гетьман та ін. Харків : Право, 2020. С. 77-81.

4. Шаблистий В.В. Професійна юридична діяльність дізнавача у контексті вимог до освітнього ступеня: погляд теоретика. Кримінальні проступки в контексті захисту прав людини: міжнародний та вітчизняний вимір : матеріали міжнар. круглого столу (25.06.2020 р., м. Одеса). 
Tetiana Mykhailichenko. Criminal offenses: features of legal regulation

The paper provides a critical analysis of the conceptual provisions of the Law of Ukraine "On Amendments to Certain Legislative Acts of Ukraine to Simplify Pre-trial Investigation of Certain Categories of Criminal Offenses” № 2617-VIII (22.11.2018), that amended the Criminal Code (next - CC) of Ukraine, establishing criminal liability for committing a criminal offense by a person in terms of identifying gaps and conflicts. Due to the emergence of criminal misconduct in the national criminal law, the latter has undergone significant changes and additions, which have reformatted traditional approaches of Ukrainian criminal law. First, the redistribution of all offenses under the CC of Ukraine into criminal offenses, minor, serious and especially serious crimes was performed. Also, in most cases criminal liability was strengthened primarily by increasing the size of fine penalty. In addition, disproportion was found in the change of fine rates.

The interconnection between "criminal offense", "crime" and "criminal misconduct" is established, the analysis of CC's Art. 12 provisions and its impact on other provisions of the CC of Ukraine is conducted. In a number of cases inaccuracies or gaps were identified, namely in the regulation of exemption from criminal liability, exemption from serving a sentence due to the expiration of the statute of limitations for execution of a conviction and criminal nature measures applicable to entities (Articles 45, 46, 80, 97, section 2 of Art. 96-7 and section 2 of Art. 106 of the CC of Ukraine).

Recurrence has been studied as a feature that characterizes qualified (especially qualified) corpus delicti, and as a circumstance that aggravates punishment. Gaps in the Art. 32 of the CC of Ukraine construction is revealed. Also, the replacement of the term "crime" with the term "criminal offense" is criticized in Art. 10 and paragraphs 1, 5, 10, 11 and 12 of section 2 of Art. 67 of the CC of Ukraine due to shortcomings.

It is proposed to adjust the provisions of Art. 10 and Art. 67 of the CC of Ukraine, replacing "crime" with "criminal offense" and to bring the provisions of the Law of Ukraine "On the application of amnesty in Ukraine" in line with the current CC of Ukraine, as well as eliminate identified discriminatory provisions in Art. 32 and 89 of the CC of Ukraine as soon as possible.

Key words: criminal offense, crime, criminal misconduct, criminal liability, recidivism, aggravating circumstances, sanction, criminal record. 